\begin{tabular}{|l|l|}
\hline Postprint Version & 1.0 \\
\hline Journal website & $\underline{\text { http://www.sciencedirect.com/science/journal/07383991 }}$ \\
\hline Pubmed link & $\begin{array}{l}\text { http://www.ncbi.nlm.nih.gov/entrez/query.fcgi?cmd=Retrieve\&db=pubmed\&dop } \\
\text { t=Abstract\&list_uids=15324982\&query_hl=59\&itool=pubmed_docsum }\end{array}$ \\
\hline DOI & $\underline{\underline{10.1016 / j . p e c .2003 .12 .009}}$
\end{tabular}

* Corresponding author. Tel.: +31-302729703; fax: +31-302729729.

E-mail address: s.vandulmen@nivel.nl (S. van Dulmen)

\title{
Observation of nurse-patient interaction in oncology: review of assessment instruments
}

\author{
WILMA CARIS-VERHALLEN ${ }^{\text {A }}$, LIESBETH TIMMERMANS ${ }^{\mathrm{B}}$, SANDRA VAN DULMEN ${ }^{\mathrm{C},{ }^{*}}$ \\ a Dutch Cancer Society, Amsterdam, The Netherlands \\ b Department of Medical Psychology, University Hospital of Nijmegen St. Radboud, Nijmegen, The \\ Netherlands \\ c NIVEL (Netherlands Institute of Health Services Research), PO Box 1568, 3500-BN Utrecht, The \\ Netherlands
}

\begin{abstract}
The aim of this review is to identify assessment instruments that can be used for analyzing sequences and can be applied to research into nurse-patient communication in cancer care. A systematic search of the literature revealed a variety of methods and instruments applicable to studies recording nurse-patient interaction. The studies that were qualitative in nature offered valuable information on observational research in general, on procedures relating to informed consent and observational arrangements in nursing practice. The quantitative studies provided an insight into the content and structure of the interaction by describing communication concepts or by frequency counts of previously determined behaviours. Systematic research into interaction sequences was not found. However, some of the quantitative instruments identified could be adapted for this purpose. The complexity and time-consuming nature of observational research highlight the need for efficiency. For instance a combination of quantitative and qualitative instruments could be considered.
\end{abstract}

\section{INTRODUCTION}

Communication is an ongoing theme in the literature on nurse-patient interaction. Major nursing tasks, such as assessing the specific needs of patients, delivering physical care, providing socioemotional support, negotiating and exchanging information, all have to do with communication and are subject to the rules of interaction. In this light, communication is recognized as an important aspect of high-quality nursing care. As a consequence, nurses need to have skills to create good interpersonal relationships, which allow them to share in the patient's experience and concerns, in addition to achieving the goals and upholding values of healthcare. This has relevance for nursing in general, but is even more important in taking care of patients suffering from a life-threatening disease such as cancer. Studies on the patient's views show that in particular people undergoing invasive treatments have special expectations of their nurses. They expect understanding, empathy and support and may consider nurses as the primary communication link to the medical system and the oncologist [1].

A female patient undergoing chemotherapy and suffering from considerable side effects put it as follows: 
"I ask the doctor more questions about the medical side. I look for practical advice about daily problems and support from the nurse. They know better what it means to have all those problems and side effects when you are at home. They show understanding and are more willing to help you find solutions for problems that cannot be solved by medication. . ."

Communication plays a major role in this. Moreover, recent studies show that communication should not be merely seen as peripheral to the actual outcome of cancer treatment [2,3]. Adequate advocacy and providing informative and emotional support may result in better coping behaviour in cancer patients, in stress reduction and even in an improved functioning of the immune system [4-7]. This means that nurses' communication skills not only reduce distress and improve cancer patients' quality of life, but may also indirectly affect the course of the disease.

Developing and expanding knowledge in the area of nurse-patient communication may contribute to the improvement of nurses' communication skills and thus to better quality of care provided by oncology nurses. To determine interaction difficulties and to evaluate whether nurses attune to their patients needs, it is necessary to study nurse-patient communication in detail. The advent of video for research purposes has brought several opportunities. One of the advantages of using video is that recordings provide multi-sensory information about both participants and the context of the interaction. Instead of assessing behaviours such as an 'open attitude', 'showing understanding' and 'being a good listener', actual verbal and nonverbal behaviour can be viewed, which offer options for describing communication difficulties or evaluating training effects. However, this demands observational techniques that do justice to the interactive nature of communication.

Since video recording was introduced in nursing practice, the number of observational studies is increasing. Various observational methods have been developed. There are qualitative studies, collecting unstructured observational data on naturally occurring communication, often completed with interviews and field notes $[8,9]$. In addition, there are more quantitative observational methods, with a molar approach, which assess general defined skills or units of activities [10,11], and observation tools with a molecular approach that count the number of predefined specific behaviours [12-14]. However, existing studies hardly pay attention to the dynamic course of the interaction, i.e. the way nurses and patients influence one another. This is an omission, because there are indications that healthcare providers' behaviours, such as their response to cues, posing open-ended questions or showing empathy, encourage patients to express their concerns $[10,15,16]$. This, in turn, may reduce patient feelings of anxiety and uncertainty [17], which provides space to assimilate information and can lead to development of effective coping strategies [18-20]. On the other hand, nurses may inhibit patients by ignoring cues, giving premature assurance or by changing the topic. These behaviours may prevent a patient from giving information and expressing concerns [10,21].

To disclose these mechanisms and observe what actually happens during a nursing encounter advanced observational instruments are needed, focusing on interaction sequences. Analyzing sequences of successive communication acts enables to investigate how patients for instance express their needs and concerns, and how nurses respond to these cues.

Clearly, only sequential analysis allows conclusions relating to the interaction, and can show that specific communication strategies influence the quality of the interaction.

Making statements on the quality of nurse-patient communication demands that both parties are taken into account $[22,23]$. Interactive data requires the analysis of sequential organization in order to identify patterns of interaction and to show how conversation partners align their utterances in the dialogue, the so-called local synchronization. Apart from that, sequential content coding of topics under discussion may provide an insight into the global structure of the nurse-patient interaction [24].

The aim of this review is to identify assessment instruments that can be used for analyzing sequences and can be applied to research into nurse-patient communication in cancer care. A comprehensive review and comparison of existing instruments in nursing research will provide an opportunity to select instruments and to build on and attune to international research, learning from other researchers' experience. Specifically, the following research questions have been addressed:

1. What observational instruments are currently used in research into communication in nursing care? 
2. Which of the observational instruments under review are applicable to sequential analysis of the nurse-patient interaction?

3. Which of the observational instruments under review are applicable to nursing care in oncology?

\section{METHODS}

In order to obtain the international literature on research into nurse-patient communication, a search was performed in the Cumulative Index of Nursing and Allied Health Literature (CINAHL) (19922001) and PubMed. The following keywords or combination of keywords were used: 'nurse-patient relationship' or 'nurse-patient communication' or 'nurse-patient interaction', combined with 'video', 'audio', 'observational study', 'assessment instruments', 'observational instruments', 'cancer care', 'oncology nursing', 'cancer nursing' (see Table 1). Because of overlap with CINAHL, in PubMed fewer keywords were used. Since the focus of our study was on medical healthcare, a study of PsychLit was considered as nonobligatory. Nevertheless, to cover relevant papers in the psychological area and area of linguistics, snowball sampling was applied. In some instances correspondence took place with the original authors. More than 550 titles and abstracts were retrieved from these searches (see Table 1).

\section{[ TABLE 1 ]}

The ultimate goal of this study was to identify instruments that could be used for analyzing sequences in nurse-patient communication. A prerequisite for the analysis of communication sequences is the collection of information on the components of communications that are readily observable, easy to record and offer data suitable for statistical procedures. Consequently, it seems reasonable to take only studies into account that are quantitative in nature. However, limiting research to quantitative studies may not give a true picture of the setting. Because it was expected that both qualitative and quantitative studies could provide relevant knowledge on measurement of nurse-patient communication, both research traditions were considered. However, to keep the data set manageable, a two-stage approach was used. In the first appraisal, aiming at a full picture of research directed at observation of nurse-patient communication (research question 1), two authors (WCV and LT) independently assessed 553 abstracts using the following inclusion criteria:

- the study was directed at the interaction of nurses and patients;

- the study involved real-time assessment or indirect observation of real-life nurse-patient interaction (i.e. by audio or videotape recording);

- the study was published in English or Dutch.

A total of 69 articles describing 46 different studies met the selection criteria of the first phase. From two studies, reporting on research in the psychiatric care setting, a reprint could not be obtained. The remaining 44 studies were included in the review, regardless of their quality (reliability and validity) and sample size.

In the next stage, within the studies included, a selection was made of studies that reported the use of instruments aiming at systematically observing nurse-patient communication. Another set of criteria had to be met for studies included in this part of the review:

- the instrument has a structured approach allowing systematic observation of components of nurse-patient communication;

- the instrument provides data suitable for quantitative analysis;

- the instrument offers the option of analyzing interaction sequences, i.e. observes behaviour units of both participants along a time trace;

- the instrument offers cues for instrument development in oncology nursing research.

To answer the second and third research question the instruments that met the latter set of criteria were studied in detail. First, a description of content and features was made. Then, methods of 
assessment, area of use, reports of reliability and validity, option for sequential analysis application and suitability for the oncology nursing setting were studied. It was inevitable that some studies are mentioned in several parts of Section 3.

\section{RESULTS}

The search strategy in the first stage of the study (answering research question 1) provided 69 articles, reporting 44 studies. Of these studies, 21 can be classified within a qualitative approach. These are presented in Table 2, arranged following research tradition and in chronological order. Twenty-three studies followed a quantitative approach and are described in Table 3. When several articles reported on the same study, only the most recently published one was described.

\section{[ TABLE 2 ]}

\subsection{Observational instruments currently used in research into communication in nursing care}

\subsubsection{Qualitative research}

The qualitative researcher seeks to identify patterns, commonalities and relationships in naturally occurring events to describe or explore reality or to develop conceptual models. In qualitative studies, data are collected with a minimum of structure in order not to overstep characteristics of the natural circumstances. Often observational data are supplemented with field notes and interviews with participants. The analysis of qualitative data is an intensive procedure, resulting in reports on the researcher's interpretation of naturally occurring events, including excerpts from 'raw' observational material as evidence or as an illustration.

The research traditions that have provided theoretical underpinnings for qualitative studies come primarily from disciplines of social sciences [25]. As Table 2 shows, there is a variety of approaches. The first three studies use ethnographic analysis, which is the primary tradition in anthropology. Naturally occurring behaviour is described and interpreted, or the assumption that verbal communication can only be adequately interpreted within the contexts in which it is used [26]. The study of Hunt [27] took place in the oncological setting, and describes different role formats used by symptom control nurses. In particular, attention was paid to how nurses actually behave in conveying feelings of friendliness and informality to seriously ill patients. Fosbinder [28] also investigated different roles in nursing. The study was performed in an acute care setting and the nursing roles were defined from the patient perspective. Mallett and A'Hern [29] describe the use of humour in nursing patients with renal failure. They combine ethnographic analysis with conversation analysis.

In the studies numbered 4-7, linguistic analysis techniques are performed. The tradition, in Table 2 referred to as discourse analysis, seeks to understand rules, mechanisms and structure of conversations. The data for this type of research are transcripts from naturally occurring conversation [25]. The Dennison study [31], carried out in the oncological setting, is particularly informative, giving insight in content and process of interaction preceding the first chemotherapy treatment.

The next three studies in Table 2 (8-10) use the grounded theory approach, embedded in the discipline of sociology. Using a procedure, referred to as constant comparison, the researcher analyses theoretical concepts in the data [34]. These studies clearly define how qualitative methods are used and may be useful in studies of nurse-patient communication $[9,35,36]$.

The studies numbered 11-14 were all undertaken on an active treatment oncology ward, and used the method of qualitative ethology, which is embedded in the psychological tradition [8,37-39]. In these studies, behavioural components are observed over time in a natural context. In each study a specific aspect of behaviour is described, providing an insight into the way nurses become attached to patients, use patterns of touch and comforting strategies.

The study of Routasalo and Isola [40] was carried out using a phenomenological approach, meaning that the analysis is focused on the lived experience of individuals. Several types of touch are described. Because touch has the potential of conveying affection, care and comfort, it is an important aspect in building rapport and establishing a relationship. 
The studies 16-21 are referred to as content analysis [41-47]. They do not fit explicitly in one of the disciplines mentioned earlier. In these studies, the researchers analyze the content of rather unstructured observational data to determine themes and patterns that are qualitative, rather than numerical in nature. In the context of this review, the study of Andersen and Adamsen [47] is particularly interesting. They discern seven communication categories employed by nurses who take care of patients undergoing brachytherapy (local implant for radiotherapeutic treatment): somatic communication, existential communication, small talk, technical talk, psychological conversation, social communication and observation procedures.

\subsubsection{Quantitative research}

In quantitative studies, events are studied that lend themselves to precise measurement and quantification. These studies are often preceded by other (qualitative) studies in which abstractions of natural concepts are defined operationally so that numerical measurement can be applied. Table 3 describes 23 studies using quantitative analysis, characterized by a structured method of observation. In these studies, general or specific communication behaviours are presented by numerical data, which are the input for statistical procedures.

\section{[ TABLE 3 ]}

In general two basic observational approaches can be discerned, which are best considered as the opposite points of a continuum. Using a molecular approach, specified units of behaviour are observed such as a verbal utterance or a gesture. On the other hand, using a molar approach, large units of behaviour are the scope of observation, such as types of activities or alterations in consciousness [25]. An example of molecular coding is the Cancer Research Campaign Interview Rating Manual (CRCIRM) [48]. This instrument is applied, reviewed and adapted in several studies in oncology settings $[16,17,49-54]$. The method enables an utterance by utterance rating of transcribed nursepatient encounters. According to some authors the need for transcription and the complexity of the coding system appear to be a time-consuming activity $[50,56]$. Consequently, efforts were made to develop a shorter rating scale, based upon the CRCIRM, and measuring only those behaviours that a validation study has shown to be effective for patient disclosure [17]. This Medical Interview Aural Rating Scale (MIARS) [57], that was applied in palliative care, is primarily directed at cues and concerns expressed by patients and tracks the professional responses to emotion [54,56].

The studies with the numbers 7-13 are all performed in elderly care. Armstrong-Esther et al. [58],Waters [59], Edberg et al. [60] and Nolan et al. [61] use molar observations, such as physical activity and non-interactive behaviour. While Davies [62], Salmon [63] and Thomas [64] use specifically defined verbal communication categories, such as explanation and jokes or puns.

The next three studies (rows 14-16) use adaptations of the Roter Interaction Analysis System (RIAS), originally designed for observation of medical consultations [65]. This molecular method has been applied in several areas in nursing such as communication in family planning, cancer nursing and elderly care [66-69]. In two studies, RIAS was extended with the observation of five nonverbal categories: patient-directed eye gaze, affirmative head nodding, smiling, forward leaning and affective touch $[66,69]$.

The studies ofWilkinson et al. $[10,70]$ investigate whether nurses pay attention to several key areas during the nursing assessment. In addition, the first study also investigates how nurses can facilitate patients talking about their problems and how nurses prevent patients from disclosure of their concerns. Both studies give insight in the content of the assessment interview and in the process of communication, especially in facilitative and blocking behaviour.

In the study of Moore and Schwartz [71], no predefined communication categories are coded, instead the amount of nurses' verbal and nonverbal behaviour is assessed, using an observation chart. This is comparable to the Holyoake study [72], although in this study attention was paid to the nature of the communication as well.

Leathart [73] studied nurses' ability to identify needs and problems of conscious intubated patients. A comparable study was applied by Hall [74], who examined the interactions between nurses and patients on ventilators. Both studies show that nurses spent only a small proportion of their time 
talking to patients, while patients who have a problem to communicate verbally, in particular, are in need for individualized communication to prevent feelings of isolation and anxiety.

The last study presented in Table 3 is an evaluation study assessing the effects of a workshop on adherence promotion [75]. In the manual used in this study, four main skills which promote adherence are described. The level of each skill is assessed by quantifying predefined component behaviours.

\subsection{Observational instruments applicable to sequential analysis of the nurse-patient interaction}

To observe whether conversation partners align to each other and show responsivity we must have an insight in the flow of verbal and nonverbal behaviour. Through systematic observation we can assign behavioural codes to the stream of activities and get an insight in the sequential organization of the interaction [76]. An appraisal of the 44 studies revealed five instruments allowing such a systematic observation and offering data suitable for analyzing sequences in interaction. Four of the instruments use a molecular approach with an utterance by utterance analysis and one uses a molar approach directed at larger units of behaviour. These five instruments, presented in Table 4, are described in more detail.

\section{[ TABLE 4 ]}

\subsubsection{Cancer research campaign interview rating manual}

The CRCIRM is devised by the CRC-funded Psychological Medicine Group in Manchester [48], to assess the impact of training programmes on communication skills $[49,55]$. In 1994 the rating manual has been adapted in order to decrease usage time, to improve the accuracy and to turn it into an accessible rating tool for tutors teaching communication skills [50]. In its present form, using the rating manual, transcripts of audiotaped conversation between healthcare workers and cancer patients are analyzed utterance by utterance, on form, function, content and structure. An utterance may be a complete sentence or a part of a sentence. Whenever there is a change of form or function, this is counted as a new utterance. The form of an utterance describes the grammatical mode. Possible forms are a statement, response and several types of questions. The function of an utterance defines the purpose of it. Possible codes are eliciting information, clarification, checking, acknowledgements and several ways of posing a hypothesis. The content ratings give an indication of the areas of information and discussion covered in the conversation, e.g. diagnosis, prognosis, social life, etc. Within the structure of an utterance characteristics are observed that give information on interaction features. For instance, the emotional level of a patient utterance is assessed, i.e. whether the nurse's response blocks or controls the patient's talks [48].

The CRCIRM is considered as a reliable and validated instrument [21] and is applied in several studies, also outside the UK. The research group of Razavi et al. [51,52] use a translation in French. Moreover, Butow et al. [77] in Australia built on CRCIRM in their study of physician-patient communication in cancer care. Coding with CRCIRM gives a broad insight into content and structure of an encounter. The data are quantifiable and open to mathematical interpretation. This method pays implicit attention to communication sequences, e.g. the relevance of an utterance is assessed and whether it is related to a patient's cue. Moreover, sequences can be studied between the professionals' blocking or facilitating behaviours and disclosure in the patient. The reported studies mainly describe frequency-based data analyses, which allow only limited conclusions about the interaction process during the nursing encounter. Nevertheless, the observation method is suitable for analyzing sequences, because by transcription a continuous real-time measurement is applied, in which interaction sequences can be traced, at least in a qualitative way.

Applying the instrument is time-consuming. Firstly, transcription is required and then it takes $2 \mathrm{~h}$ to rate a 15 min interview $[50,56]$. In addition, coding each utterance in several modes will lead to a very large complicated data set. Computer software may ease coding procedures, and will provide the observational data in an accessible way. Up till now, research papers on the CRCIRM do not report on computer-assisted coding methods. 


\subsubsection{Medical Interview Aural Rating Scale}

The MIARS was developed to assess whether nurses use adequate communication skills during encounters with cancer patients [57]. The instrument, which builds on the CRCIRM, is especially directed at providers' communication related to patient's disclosure. The categories are therefore not exhaustive and not mutually exclusive. The basic unit rated is each turn of speech, for both the nurse and the patient [56].

Using the rating scale, several types of interviewers' behaviours are assessed, that all had been shown to have a significant effect on patient disclosure, such as open questions, summary or problem-focused behaviour. On the side of the patient two types of disclosure are rated: cues and concerns. Five interviewers' cue responses are also assessed, such as exploration of the cue or use of distancing strategies. The instrument has recently been developed and therefore applied on a limited basis in the research practice. Nevertheless, the first application in a study of the palliative setting has shown that the instrument is reliable [57]. Comparable to the CRCIRM system the observation method is suitable for sequential analysis, because continuous real-time measurement is employed.

\subsubsection{Roter interaction analysis system}

The RIAS was originally designed to assess physician- patient communication [65]; however, several adaptations have been made to use it in nursing practice. Apart from applications in elderly nursing $[13,66,78]$ and family planning sessions $[67,68]$, it was also used to rate assessment interviews of nurses with admitted cancer patients [14]. The scheme uses a molecular approach, coding verbal utterances. An utterance is defined as the smallest distinguishable speech segment to which a coder can assign a classification, so one speaking turn can include several utterances. All utterances are assigned to mutual exclusive and exhaustive categories. In its original form there are 34 verbal categories, discernible in instrumental and affective verbal behaviours. A general assessment of the atmosphere during the interaction is reflected in a rating of general affect dimensions, including anger, nervousness, assertiveness, interest, friendliness and involvement. In some of the application fields the observation is extended to nonverbal behaviour $[13,14]$.

Coders apply RIAS directly from video or audiotape, without transcription, using a computer system. RIAS coding is easily learned and after training experienced coders can reach speed in coding, meaning that an uncomplicated coding task requires $150 \%$ real-time interaction [79]. From coding, quantitative indexes of the communication categories can be computed and used in statistical models, either to describe content and structure of the communication or as a dependent variable, e.g. to test the effectiveness of an intervention [14,69] or as a predictor of outcomes of interest, such as patient satisfaction, information recall, etc. [80]. Interrater reliability and validity measures in the oncological setting have been reported $[69,81]$.

A drawback of RIAS is that it provides only frequency data, and these allow limited conclusions on the interactive nature of the communication. In one of the reported studies authors pay attention to a two-way interaction process, for instance by calculating the total amount of talk by participants and ratios of provider to patient talk, as an indicator of verbal dominance [66]. Kim et al. made a start to adapt RIAS for sequential analysis [68]. She developed a separate coding guide to analyze pairs of utterances, aiming at exploring provider's response to client's efforts to play an active role during the encounter. The method needs further elaboration. Communication with the author (D.L. Roter) demonstrated that a computerized RIAS coding program has been developed, in which sequential information is stored, suitable for giving feedback on interaction sequences for training purposes. Systematic sequential analyses for research purposes have not been reported so far.

Dutch researchers in the field of physician-patient communication report on data entry, using 'The observer' [82]. This system allows to perform lag sequential analysis. This type of analysis [76] examines how often certain events, for instance 'patient disclosure', are preceded or followed by other events, such as 'provider's expressions of empathy'. 'The observer' has been reported as compatible with the recently developed advanced computer program 'Theme', especially developed for pattern recognition in human interactions [83]. Further study is needed to determine whether this program could be useful in analyzing sequences of nurse-patient interaction.

\subsubsection{Measuring adherence promotion counseling skills}


To evaluate a workshop for improving counseling skills of healthcare professionals, Schlundt et al. [75] developed a coding system to assess skills from videotaped provider-patient encounters. In the system four categories of adherence skills were defined: relationship building, interviewing, problem diagnosis and behavioural intervention. Within each category, major skills are defined, each further divided into component skills, resulting in a molecular approach, with a list of specific, observable and operationally defined behaviours. For instance, within the relationship building category, a major skill was demonstrating respect for the patient. A list of positive behaviours (greeting, politeness) and negative behaviours (ignoring patient, time pressure, inappropriate self-disclosure) was defined. The manual that was obtained from the authors showed that the skills and observable behaviours were clearly identified and specified. The level of each skill was quantified using judgments of presence or absence, ratings of appropriateness or frequency counts, resulting in numerical scores. No special attention was paid to interaction sequences. However, if speaking turns are coded continuously along a time trace, the system could be suitable for this.

\subsubsection{Coverage of key areas of nursing assessment}

Wilkinson [10] developed a molar form of assessing communication of nurses and patients during an assessment interview. Actually, they discern several areas in the nursing encounter, that all need to be directed, and in that way constitute a global sequence in the interaction: the introduction of the assessment, patient's understanding of admission, patient's awareness of diagnosis, history of present illness, history of previous illness, physical assessment, social assessment, psychological assessment and the closure of nursing assessment. The instrument has proved to be reliable, but validity has not been reported $[10,70]$. The system proved to be an appropriate means to analyze a series of meaningful stages subsequently discussed during the assessment interview. Such a global sequence could not be distinguished by analyzing the frequency coding of small speech units. A limitation is that no insight is provided into the way nurses' communication is closely attuned to the individual. Also information on involvement and attitude of nurses is limited because the focus is only on coverage of key areas. A key area may be adequately covered, while the nurse is distant and ignores patient emotions.

\subsection{Observation instruments applicable to research into nurse-patient communication in oncology}

As was shown in Table 2, a lot of researchers have made use of qualitative studies to study nursepatient communication in daily practice. These studies give valuable information on observational research in general, procedures concerning informed consent and observation arrangements in nursing practice. For instance, Latter et al.'s study on medical education (Table 2, row 19) gives an example how to include both patient and nurse characteristics and contextual factors in the study of interaction [45]. The studies conducted in the different oncological settings in particular provide relevant background information for designing studies in cancer nursing (see right-most column in Table 2). The Dennison study gives an insight in content and process of interaction guiding patients during the first chemotherapy session [31]. Several studies are helpful in developing content categories for observational instruments because they describe communication aspects in detail. The study by Hunt, for example, describes different role formats used by symptom control nurses [27]. More specifically, an insight is provided in how nurses communicate to convey a friendly and informal attitude, both verbally and nonverbally. Jarrett and Payne describe how 'optimistic communication' cannot simply be considered as 'chatty behaviour' but may have a function of 'constructive realism', which seems to be very useful in cancer care [33]. Studies by Bottorff et al. are very informative in describing how nurses become attached to patients and give comfort [37-39]. The studies of touch $[8,40]$ show how important touch is in building a relationship and providing care and comfort. Therefore, this is an aspect of communication that should be considered in the study of nurse-patient interaction in oncology. Finally, the study by Andersen and Adamsen, who use a partly quantitative approach, offers suggestions for instrument development, concerning different types of communication during the administration of a radiation therapy [47].

As regards the quantitative studies (Table 3), it may be concluded that some of them are performed in a context that differs strongly from oncology nursing. For instance, the studies in elderly care $[59,61-63]$ or in the intensive care $[73,74]$ do not offer specific clues for instrument development in 
oncology care. Studies directed at the occurrence of verbal and nonverbal behaviour, rather than the content of communication [71,72], neither offer guidelines for instrument development in cancer nursing (right-most column in Table 3). The study of Schlundt et al. [75], though not applied in oncology, could be valuable. Although this manual was primarily directed at skills in promoting adherence, most of the behaviours defined, such as empathy, negotiating and social support, are important in cancer care.

The CRCIRM [48] has been specially developed for the oncological setting, resulting in measurement of distinctive and special features of the interaction in this area. The method has been utilized in several studies and the scheme has proved to be sensitive to changes in communication and patient's disclosure [21]. Because the use of CRCIRM is time-consuming, depending on the research question, it may be worth using the MIARS, which is derived from CRCIRM, but less extensive.

Wilkinson et al.'s instrument [70] has also been developed in the oncological setting. This instrument is especially valuable when describing a series of topics discussed during a nursing encounter.

The RIAS, though not specifically developed for the oncological setting, has proved to be suitable for describing interactions in cancer care $[14,81]$. However, borrowing instruments developed for interaction in a medical context has constraints. Medicine differs from nursing in important ways [84]. Communication in doctor-patient consultations is mainly characterized by diagnosing and medical problem solving. Socio-emotional communication, although considered as important, has a subordinate role and is mainly used to facilitate the problem solving process. In nursing, on the contrary, the process of care is an important aspect. Within the caring relationship problem solving is closely intertwined with the provision of psycho-social support, in the broadest sense [85].

\section{DISCUSSION AND CONCLUSION}

This article has presented and discussed observation instruments currently used in nursing research. Special attention was paid to applicability of these instruments to sequential analysis and their suitability for the oncological setting. The overview of studies demonstrates a variety of methods assessing nurse-patient communication. Nearly half of the studies in review used a qualitative approach. Especially, because these studies are directed at the interaction as it occurs in its daily context, they seem to be extremely profitable for understanding communication within a specific environment. Consequently, the studies in oncology nursing provide relevant background information for problem definition and designing research that is more quantitative in nature.

\subsection{Discussion}

The studies using quantitative techniques were often used to evaluate effects of training. Several observation systems appeared to be suitable for analyzing sequences in the oncological setting. RIAS [65] and CRCIRM [48] are both sophisticated systems and allow for rating patients' and nurses' communication. Especially CRCIRM, that has its roots in oncological care, covers a wide scope of the interaction, providing insight in both function form and content of the conversation. However, the need for transcription and the complexity of the coding system can be considered as serious drawbacks. In that respect, MIARS could offer a better choice, measuring only those behaviours that a validation study has shown to be significantly related to patient's disclosure of concerns [57]. Both CRCIRM and MIARS lack a direct assessment of nonverbal behaviour, meaning that nonverbal cues of a patient and cues missed by the nurse are not identified. As socio-emotional communication, in particular, is transferred in a nonverbal way, adaptations of these systems for observing nonverbal communication should be studied.

In general, observational research is a laborious and time-consuming matter. Especially when analyzing larger sample sizes, efforts must be taken to use the selected methods more efficiently. Several possibilities have potential in this regard. One could use a sample procedure by which only a part of an encounter is coded. For example, observing the first $10 \mathrm{~min}$ of an encounter. Doing this, one should empirically verify whether the segment of the interaction is comparable with the speech pattern of the entire interaction $[12,78,86]$. Another possibility is to identify specific events, based on operationally defined research questions. Such a specific event, for instance a topic change [87] including several conversational turns before and after, could be analyzed in detail, and may answer questions such as, who initiates a topic change and what may prompt a nurse to change the topic? Finally, a combination of instruments could be considered. For instance, the use of a molar system 
[70] to identify a specific phase of the admission interview, such as talking about patient's treatment, and subsequently, apply a molecular observation for an analysis of targeting behaviours or sequences during this specific phase. A prerequisite for efficiently selecting and combining instruments for assessing interaction is a well defined and specific research question.

\subsection{Practice implications and future research}

Communication is essential for the provision of tailored and sensitive nursing care. Research can contribute to knowledge in this area, and as such serve as a basis for nurses' education.

However, simply giving nurses new protocols to follow is not enough to change patterns of interaction. Educational programmes should be evidence-based and pay attention to both verbal and nonverbal communication in realistic situations. Good measurement tools are needed to detect inadequate and adequate communication patterns.

Evaluating the preceding review we may conclude that there are several observation methods that are more or less suitable for research into nurse-patient communication in cancer care. A molecular method will not always be the most efficient one. After all, reducing the observations to concrete and specific elements may risk losing sight of the activities that are at the heart of the interaction. Our results show that in some instances a combination of molar and molecular instruments would be a better choice and a more efficient one, while in other situations a molecular approach in combination with qualitative methods assessing the context and atmosphere is preferable.

\section{ACKNOWLEDGEMENTS}

This research project is funded by the Dutch Cancer Foundation. The authors wish to thank the following researchers for responding to our request for information and their willingness to contribute further materials: C.M. Heaven, Y.M. Kim, M. Magnusson, D.L. Roter, D.G. Schlundt.

\section{REFERENCES}

[1] The BAM. Palliatieve behandeling en communicatie: een onderzoek naar optimisme op herstel van longkankerpatiënten [Palliative treatment and communication: a study into optimism about recovery in lung cancer patients]. Houten: Bohn Stafleu Van Loghum, 1999.

[2] Thorne SE. Communication in cancer care: what science can and cannot teach us. Cancer Nurs 1999;22:370-8.

[3] Spiegel D, Sephton SE. Psychoneuroimmune and endocrine pathways in cancer: effects of stress and support. Semin Clin Neuropsychiatr 2001;6:252-2565.

[4] Spiegel D, Bloom JR, Kraemer HC, Gottheil E. Effect of psychosocial treatment on survival of patients with metastatic breast cancer. Lancet 1989;8668:888-91.

[5] Schilder H. Paradox and confrontation in spontaneous regression in cancer. In: Mulder CL, editor. Psychological interventions in patients with cancer and coronary heart disease: examples of field studies and methodological considerations. Amsterdam: Swets \& Zeitlinger, 1993.

[6] Anderson B. Quality of life in progressive ovarian cancer. Gynecol Oncol 1994;55:S151-5.

[7] Spiegel D. Mind matters: coping and cancer progression. J Psychosom Res 2001;50:287-90.

[8] Bottorff JL. The use and meaning of touch in caring for patients with cancer. Oncol Nurs Forum 1993;20:1531-8.

[9] Hewison A. Nurses' power in interactions with patients. J Adv Nurs 1995;21:75-82.

[10] Wilkinson S. Factors which influence how nurses communicate with cancer patients. J Adv Nurs 1991;16:677-88.

[11] Fallowfield L, Saul J, Gilligan B. Teaching senior nurses how to teach communication skills in oncology. Cancer Nurs 2001;24:185-91.

[12] Caris-Verhallen WMCM, Kerkstra A, van der Heijden PGM, Bensing JM. Nurse-elderly patient communication in home care and institutional care: an explorative study. Int J Nurs Stud 1998;35:95-108.

[13] Caris-Verhallen WMCM. Nurse-patient communication in elderly care. Utrecht: Nivel, 1999.

[14] Kruijver IPM. Communication between nurses and admitted cancer patients: the evaluation of a communication training program. Utrecht: Nivel, 2001.

[15] Morales E. Meaning of touch to hospitalized Puerto Ricans with cancer. Cancer Nurs 1994;17:464-9.

[16] Booth K, Maguire P, Butterworth T, Hillier VF. Perceived professional support and the use of blocking behaviours by hospice nurses. J Adv Nurs 1996;24:522-7. 
[17] Maguire P, Faulkner A, Booth K, Elliott C, Hillier VF. Helping cancer patients disclose their concerns. Eur J Cancer 1996;32:78-81.

[18] van Dulmen AM. Exploring cognitions in irritable bowel syndrome: implications for the role of the doctor. Nijmegen: KUN, 1996.

[19] Kelley JE, Lumley MA, Leisen JCC. Health effects of emotional disclosure in rheumatoid arthritis patients. Health Psychol 1997;16:331- 40.

[20] De Leeuw JRJ, De Graeff A, Ros WJ, Hordijk GJ, Blijham GH, Winnubst JAM. Negative and positive influences of social support on depression in patients with head and neck cancer: a prospective study. Psycho-oncology 2000;9:20-8.

[21] Booth K, Maguire P, Hilier VF. Measurement of communication skills in cancer care: myth or reality? J Adv Nurs 1999;30:1073-9.

[22] Jarrett NJ, Payne S. A selective review of the literature on nurse-patient communication: has the patient's contribution been neglected? J Adv Nurs 1995;22:72-8.

[23] Cegala D, McClure L, Marinelli TM, Post DM. The effects of communication skills training on patients' participation during medical interviews. Patient Educ Couns 2000;41:209-22.

[24] Gilotti C, Thompson T, McNeilis KS. Communicative competence in the delivery of bad news. Soc Sci Med 2002;54:1011-23.

[25] Polit DF, Hungler BP. Nursing research: principles and methods. Philadelphia: Lippincott, 1999.

[26] Garfinkel H. Studies in ethnomethodology. Oxford: Polity Press Cambridge/ Blackwell, 1984.

[27] Hunt M. Being friendly and informal: reflected in nurses', terminally ill patients' and relatives' conversations at home. J Adv Nurs 1991;16:929-38.

[28] Fosbinder D. Patient perceptions of nursing care: an emerging theory of interpersonal competence. J Adv Nurs 1994;20:1085-93.

[29] Mallett J, A'Hern R. Comparative distribution and use of humour within nurse-patient communication. Int J Nurs Stud 1996;33:530- 50.

[30] Van Cott ML. Communicative competence during nursing admission interviews of elderly patients in acute care settings. Qual Health Res 1993;3:184-208.

[31] Dennison S. An exploration of the communication that takes place between nurses and patients whilst cancer chemotherapy is administered. J Clin Nurs 1995;4:227-33.

[32] Proctor A, Morse JM, Khonsari ES. Sounds of comfort in the trauma center: how nurses talk to patients in pain. Soc Sci Med 1996;42:1669-80.

[33] Jarrett NJ, Payne SA. Creating and maintaining 'optimism' in cancer care communication. Int J Nurs Stud 2000;37:81-90.

[34] Glaser BG, Strauss AL. The discovery of the grounded theory: strategies for qualitative research. Chicago: Aldine, 1967.

[35] Rundell S. A study of nurse-patient interaction in a High Dependency Unit. Intens Care Nurs 1991;3:171-8.

[36] Fenwick J, Barclay L, Schmied V. 'Chatting': an important clinical tool in facilitating mothering in neonatal nurseries. J Adv Nurs 2001;33:583-93.

[37] Bottorff JL, Morse JM. Identifying types of attending: patterns of nurses work. J Nurs Scholarship 1994;26:53-60.

[38] Bottorff JL, Gogag M, Engelberg-Lotzkar M. Comforting: exploring the work of cancer nurses. J Adv Nurs 1995;22:1077-84.

[39] Bottorff JL, Varcoe C. Transitions in nurse-patient interactions: a qualitative ethology. Qual Health Res 1995;5:315-31.

[40] Routasalo P, Isola A. Touching by skilled nurses in elderly nursing care. Scand J Caring Sci 1998;12:170-8.

[41] Kihlgren M, Norberg A, Bråne G, Engström B, Melin E. Nurse-patient interaction after training in integrity promoting care at a long-term ward: analysis of video-recorded morning care sessions. Int J Nurs Stud 1993;30:1-13.

[42] Elliott R, Wright L. Verbal communication: what do critical care nurses say to their unconscious or sedated patients? J Adv Nurs 1999;29:1412-20.

[43] Latvala E, Janhonen S, Wahlberg KE. Patient initiatives during the assessment and planning of psychiatric nursing in a hospital environment. J Adv Nurs 1999;29:64-71.

[44] Latvala E, Vuokila-Oikkinen P, Janhonen S. Videotaped recording as a method of participant observation in psychiatric nursing research. J Adv Nurs 2000;31:1252-7.

[45] Latter S, Yerrell P, Rycroft-Malone J, Shaw D. Nursing, medication education and the new policy agenda: the evidence base. Int J Nurs Stud 2000;37:469-79.

[46] Vivian BG, Wilcox JR. Compliance communication in home health care: a mutually reciprocal process. Qual Health Res 2000;10:103- 16. 
[47] Andersen C, Adamsen L. Continuous video recording: a new clinical research tool for studying the nursing care of cancer patients. J Adv Nurs 2001;35:257-67.

[48] Cancer Research Campaign Psychological Medicine Group CRC Interview Rating Manual. Stanley House, Christie Hospital, Manchester: CRC Psychological Medicine Group, 1994.

[49] Faulkner A. The evaluation of training programmes for communication skills in palliative care. Eur J Cancer 1992;1:75-8.

[50] Argent J, Faulkner A, Jones A, O'Keefe C. Communication skills in palliative care: development and modification of a rating scale. J Med Educ 1994;28:559-65.

[51] Razavi D, Delvaux N, Marchal S, Bredart A, Farvaques C, Paesmans M. The effects of a 24-h psychological training program on attitudes, communication skills and occupational stress in oncology: a randomised study. Eur J Cancer 1993;29A:1858-63.

[52] Razavi D, Delvaux N, Marchal S, De-Cock M, Farvacques C, Slachmuylder JL. Testing health care professionals' communication skills: the usefulness of highly emotional standardized roleplaying sessions with simulators. Psycho-oncology 2000;9:293-302.

[53] Faulkner A, Argent J, Jones A. Effective communication in health care: exploring the skills of the teachers. Patient Educ Couns 2001;45:227-32.

[54] Heaven CM, Maguire P. Training hospice nurses to elicit patient concerns. J Adv Nurs 1996;23:280-6.

[55] Maguire $\mathrm{P}$, Booth $\mathrm{K}$, Elliott $\mathrm{C}$, Jones $\mathrm{B}$. Helping health professionals involved in cancer care acquire key interviewing skills. The impact of workshops. Eur J Cancer 1996;32A:1486-9.

[56] Heaven CM. The role of clinical supervision in communication skills training. Unpublished Ph.D. Thesis. Stanley House, Christie Hospital, Manchester: Psychological Medicine Group, 2001.

[57] Heaven CM, Green C. Medical Interview Aural Rating Scale. Stanley House, Christie Hospital, Manchester: Psychological Medicine Group, 2001.

[58] Armstrong-Esther CA, Browne KD, McAfee JG. Elderly patients: still clean and sitting quietly. J Adv Nurs 1994;19:264-71.

[59] Waters KR. Getting dressed in the early morning: styles of staff/patient interaction on rehabilitation hospital wards for elderly people. J Adv Nurs 1994;19:239-48.

[60] Edberg AK, Hallberg IR, Gustafson L. Effects of clinical supervision on nurse-patient cooperation quality: a controlled study in dementia care. Clin Nurs Res 1996;5:127-49.

[61] Nolan M, Grant G, Nolan J. Busy doing nothing: activity and interaction levels amongst differing populations of elderly patients. J Adv Nurs 1995;22:528-38.

[62] Davies SM. Consequences of division of nursing labour for elderly patients in a continuing care setting. J Adv Nurs 1992;17:582-9.

[63] Salmon P. Interactions of nurses with elderly patients: relationship to nurses' attitudes and to formal activity periods. J Adv Nurs 1993;18:14-9.

[64] Thomas LH. A comparison of the verbal interactions of qualified nurses and nursing auxiliaries in primary, team and functional nursing wards. Int J Nurs Stud 1994;31:231-44.

[65] Roter DL. The Roter method of interaction process analysis. Baltimore: The Johns Hopkins University, 2001.

[66] Caris-Verhallen WMCM, Kerkstra A, Bensing JM, Grypdonck MHF. Effects of video interaction analysis training on nurse-patient communication in the care of the elderly. Patient Educ Couns 2000;39:91- 103.

[67] Kim YM, Odallo D, Thuo M, Kols A. Client participation and provider communication in family planning counseling: transcript analysis in Kenya. Health Commun 1999;11:1-19.

[68] Kim YM, Kols A, Mwarogo P, Awasum D. Differences in counseling men and women: family planning in Kenya. Patient Educ Couns 2000;39:37-47.

[69] Kruijver IPM, Kerkstra A, Bensing JM, van de Wiel HBM. Communication skills of nurses during interactions with simulated cancer patients. J Adv Nurs 2001;34:772-9.

[70] Wilkinson S, Roberts A, Aldridge J. Nurse-patient communication in palliative care: an evaluation of a communication skills programme. J Palliat Med 1998;12:13-22.

[71] Moore KW, Schwartz KS. Psychosocial support of trauma patients in the emergency department by nurses, as indicated by communication. J Emerg Nurs 1993;19(4):297-302.

[72] Holyoake D. Observing nurse-patient interaction. Nurs Stand 1998;12:35-8.

[73] Leathart AJ. Communication and socialisation (1): an exploratory study and explanation for nurse-patient communication in an ITU. Intens Crit Care Nurs 1994;10:93-104.

[74] Hall DS. Interactions between nurses and patients on ventilators. Am J Crit Care 1996;5:293-7.

[75] Schlundt DG, Quesenberry L, Pichert JW, Lorenz RA, Boswell EJ. Evaluation of a training programme for improving adherence promotion skills. Patient Educ Couns 1994;24:165-73. 
Caris-Verhallen, W., Timmermans, L., Dulmen, S. van

Observation of nurse-patient interaction in oncology: review of assessment instruments.

Patient Education and Counseling: 54, 2004, p. 307-320

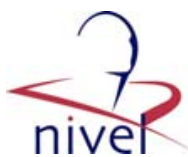

[76] Bakeman R, Gottman JM. Observing interaction: an introduction to sequential analysis. New York: Cambridge University Press, 1997.

[77] Butow PN, Dunn SM, Tattersall MHN, Jones QJ. Computer-based interaction analysis of the cancer consultation. Br J Cancer 1995;71:1115-21.

[78] Caris-Verhallen WMCM, Kerkstra A, Bensing JM. Non-verbal behaviour in nurse-elderly patient communication. J Adv Nurs 1999;29:808-18.

[79] Roter DL, Larson S. The relationship between residents' and attending physicians' communication during primary care visits: an illustrative use of the Roter Interaction Analysis System. Health Commun 2001;13:33-48.

[80] Street RL, Millay B. Analyzing patient participation in medical encounters. Health Commun 2001;13:61-73.

[81] Ong LML, Visser MRM, Kruijver IPM, Bensing JM, Brink-Muinen Avd, Stouthard JML, Lammes FB, Haes JCJMd. The Roter Interaction Analysis System (RIAS) in oncological consultations: psychometric properties. Psycho-oncology 1998;7:387-401.

[82] Noldus LPJJ, Trienes RJH, Hendriksen AHM, Jansen H, Jansen RG. The Observer Video-Pro: new software for the collection, management, and presentation of time-structured data from videotapes and digital media files. Behav Res Methods Instrum Comput 2000;32:197-206.

[83] Magnusson MS. Discovering hidden time patterns in behavior: T-patterns and their detection. Behav Res Methods Instrum Comput 2000;32:93-110.

[84] Bakker DA, Fitch MI, Gray R, Reed E, Bennett J. Patient-health care provider communication during chemotherapy treatment: the perspectives of women with breast cancer. Patient Educ Couns 2001;43:61-71.

[85] Benner P. From novice to expert. Excellence and power in clinical nursing practice. Menlo Park, CA: Addison-Wesley, 1984.

[86] Henbest RJ, Fehrsen GS. Patient-centredness: is it applicable outside the West? Its measurement and effect on outcomes. Fam Pract 1992;9:311-7.

[87] McNeilis KS. Analyzing communication competence in medical consultations. Health Commun 2001;13:5-18.

\section{TABLES}

Table 1

The numeric results of the literature search

\begin{tabular}{|c|c|c|c|}
\hline Source & Search terms & Hits & Selected for retrieval \\
\hline \multirow[t]{4}{*}{ CINAHL } & $\begin{array}{l}\text { (a) nurse-patient relationship/nurse-patient communication/nurse-patient } \\
\text { interaction (1) }\end{array}$ & 1068 & $252^{\mathrm{a}}$ \\
\hline & (b) 1 AND cancer nursing/oncology nursing & 171 & 128 \\
\hline & (c) 1 AND observational study/video/audio & 142 & 89 \\
\hline & (d) 1 AND assessment instruments/observational instruments & 80 & 39 \\
\hline PubMed & nurs $^{\mathrm{a}}$ AND communicat ${ }^{\mathrm{a}}$ AND (video OR audio) & 122 & $34^{\mathrm{b}}$ \\
\hline Snowball sampling & & & 8 \\
\hline \multirow[t]{2}{*}{ Correspondence with specialists } & & & 3 \\
\hline & Total & & 553 \\
\hline
\end{tabular}

a Retrieved in a second appraisal, after the narrowed approaches (b), (c) and (d)

${ }^{\mathrm{b}}$ Not duplicated in CINAHL. 
Caris-Verhallen, W., Timmermans, L., Dulmen, S. van

Observation of nurse-patient interaction in oncology: review of assessment instruments.

Patient Education and Counseling: 54, 2004, p. 307-320

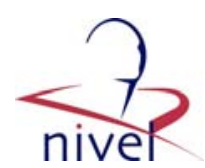

Table 2

Qualitative studies in nursing practice

\begin{tabular}{|c|c|c|c|c|c|c|c|}
\hline & Source & Setting and sample & Study focus & Data collection & Research tradition & $\begin{array}{l}\text { Interaction } \\
\text { partners } \\
\text { considered }\end{array}$ & $\begin{array}{l}\text { Cues for instrument } \\
\text { development in } \\
\text { oncology }\end{array}$ \\
\hline 1 & [27] & Palliative home care; 5 nurses; 54 patients & Nurse's role in symptom control & $\begin{array}{l}\text { Audio recordings of naturally occurring } \\
\text { nurse-patient conversations }\end{array}$ & Ethnographic analysis & Both & Yes \\
\hline 2 & [28] & $\begin{array}{l}\text { Acute care in a private hospital; } 12 \text { nurses; } 40 \\
\text { patients; } 245 \text { observations }\end{array}$ & $\begin{array}{l}\text { Interpersonal competence among nurses from the } \\
\text { perspectives patients }\end{array}$ & $\begin{array}{l}\text { Participant observation, completed with patient } \\
\text { interviews }\end{array}$ & Ethnographic analysis & Both & No \\
\hline 3 & [29] & $\begin{array}{l}\text { Specialized unit for haemodialyse; } 5 \text { patients and } \\
\text { nurses involved }\end{array}$ & $\begin{array}{l}\text { Humour within nurse-patient communication: frequency, } \\
\text { distribution and use of humour }\end{array}$ & $\begin{array}{l}\text { Videotaped nurse-patient interactions, with a } \\
\text { hand-held camera }\end{array}$ & $\begin{array}{l}\text { Ethnographic analysis; } \\
\text { conversation analysis }\end{array}$ & Mainly nurse & No \\
\hline 4 & [30] & $\begin{array}{l}\text { Acute care hospital unit; } 20 \text { nurses; } 20 \text { elderly } \\
\text { patients }\end{array}$ & $\begin{array}{l}\text { Speech events during admission interviews, focusing at } \\
\text { acoustics, phonology, syntax, lexicon, conceptions, } \\
\text { intent, credence }\end{array}$ & $\begin{array}{l}\text { Audio recordings of admission interviews in } \\
\text { the natural setting }\end{array}$ & Discourse analysis & Both & No \\
\hline 5 & [31] & $\begin{array}{l}\text { Specialized gynaecological oncology unit; } 8 \text { nurses } \\
\text { each caring for a patient }\end{array}$ & $\begin{array}{l}\text { Communication that takes place between nurses and } \\
\text { patients whilst cancer chemotherapy is administered }\end{array}$ & $\begin{array}{l}\text { Audiotapes of nurse-patient conversations in } \\
\text { the natural setting }\end{array}$ & Discourse analysis & Both & Yes \\
\hline 6 & [32] & $\begin{array}{l}\text { Hospital trauma rooms; } 67 \text { patients and nurses } \\
\text { involved }\end{array}$ & $\begin{array}{l}\text { Language of trauma centre nurses to distressed patients, } \\
\text { special focus on linguistic features and intonation } \\
\text { patterns of comfort talk }\end{array}$ & $\begin{array}{l}85 \mathrm{~h} \text { of real live nurse-patient interactions } \\
\text { were videotaped }\end{array}$ & Analysis of speech & Mainly nurse & No \\
\hline 7 & [33] & $\begin{array}{l}\text { Outpatient department for radiotherapy and } \\
\text { chemotherapy, } 8 \text { nurses; } 9 \text { patients }\end{array}$ & $\begin{array}{l}\text { Themes in communication: relationship building; } \\
\text { helping the patients, knowledge, optimism }\end{array}$ & $\begin{array}{l}266 \mathrm{~min} \text { of audio-recorded nurse-patient } \\
\text { conversations, supplemented with } \\
\text { semi-participant observation and patient } \\
\text { interviews }\end{array}$ & Conversation analysis & Both & Yes \\
\hline 8 & [9] & $\begin{array}{l}\text { Site in a small hospital for elderly patients; } 9 \\
\text { nurses; } 24 \text { patients }\end{array}$ & $\begin{array}{l}\text { Nurses' power in language: persuasion and controlling } \\
\text { the agenda }\end{array}$ & $\begin{array}{l}37.5 \mathrm{~h} \text { of participant observation; recorded } \\
\text { verbatim and field notes }\end{array}$ & Grounded theory approach & Nurse & No \\
\hline 9 & [35] & High dependency unit; 5-day shifts in a 2-bed HDU & $\begin{array}{l}\text { Characteristics of natural occurring interactions in a } \\
\text { high dependency unit }\end{array}$ & $\begin{array}{l}\text { Videotape recordings of natural occuring } \\
\text { interactions, supplemented with participant } \\
\text { observation }\end{array}$ & Grounded theory approach & Both & No \\
\hline 10 & [36] & $\begin{array}{l}\text { Special care nurseries for premature infants; } 20 \\
\text { nurses; } 31 \text { mothers of premature infants }\end{array}$ & $\begin{array}{l}\text { The use of chat and social talk as a clinical tool } \\
\text { applied to facilitate parents in neonatal caring }\end{array}$ & $\begin{array}{l}\text { Audio recordings of nurse-patient interactions, } \\
\text { supplemented with interviews and field notes }\end{array}$ & Grounded theory approach & Mainly nurse & No \\
\hline 11 & [8] & $\begin{array}{l}\text { Active treatment oncology ward; } 32 \text { nurses; } 8 \\
\text { patients }\end{array}$ & $\begin{array}{l}\text { Different types of touch: comforting touch, connecting } \\
\text { touch, working touch, orienting touch and social touch }\end{array}$ & $\begin{array}{l}\text { Videotaped nurse-patient interactions, supported } \\
\text { with interviews with patient and nurses }\end{array}$ & Qualitative ethology & Mainly nurse & Yes \\
\hline 12 & [37] & $\begin{array}{l}\text { Active treatment oncology ward; } 32 \text { nurses; } 8 \\
\text { patients; } 1085 \text { interaction units }\end{array}$ & Types of nursing behaviour in different contexts of care & $\begin{array}{l}\text { Videotaped nurse-patient interactions, } \\
\text { supported with audiotaped interviews with } \\
\text { patient and nurses }\end{array}$ & Qualitative ethology & Mainly nurse & Yes \\
\hline 13 & [38] & $\begin{array}{l}\text { Active treatment oncology ward; } 32 \text { nurses; } 8 \\
\text { patients; } 116 \text { selected interactions }\end{array}$ & $\begin{array}{l}\text { Verbal and nonverbal behaviours of patient and nurses, } \\
\text { with a special focus on transitions in the interaction }\end{array}$ & $\begin{array}{l}\text { Real live videotaped nurse-patient interactions, } \\
\text { supplemented with field notes }\end{array}$ & Qualitative ethology & Mainly nurse & Yes \\
\hline 14 & [39] & $\begin{array}{l}\text { Active treatment cancer ward; } 32 \text { nurses; } 8 \\
\text { patients, each videotaped for } 72 \mathrm{~h}\end{array}$ & $\begin{array}{l}\text { Comforting behaviours of nurses: physical comfort; } \\
\text { providing information; supportive statements proximity; } \\
\text { touch }\end{array}$ & $\begin{array}{l}\text { Real live videotaped nurse-patient interactions, } \\
\text { supplemented with field notes }\end{array}$ & Qualitative ethology & Mainly nurse & Yes \\
\hline 15 & [40] & $\begin{array}{l}\text { Ward in long-term care institutions; } 10 \text { care } \\
\text { situations }\end{array}$ & Frequency and types of touch & $\begin{array}{l}\text { Video recordings of real live nursing care } \\
\text { situations }\end{array}$ & Phenomenological approach & Both & Yes \\
\hline 16 & [41] & $\begin{array}{l}\text { Two long-term wards in different nursing homes; } \\
10 \text { nurses; } 10 \text { patients }\end{array}$ & $\begin{array}{l}\text { The effect of training promoting integrity care on } \\
\text { patterns of interaction }\end{array}$ & Video-recorded real live morning care sessions & $\begin{array}{l}\text { Qualitative content analysis, } \\
\text { events analysis }\end{array}$ & Both & No \\
\hline 17 & [42] & $\begin{array}{l}\text { Adult intensive care unit in a general hospital; } 16 \\
\text { nurses }\end{array}$ & $\begin{array}{l}\text { Quantity and content of verbal communication in } \\
\text { critical care nursing }\end{array}$ & $\begin{array}{l}\text { Non-participant observation of } 4 \mathrm{~h} \text { episodes, } \\
\text { each utterance was written down }\end{array}$ & $\begin{array}{l}\text { Qualitative content analysis, } \\
\text { time analysis }\end{array}$ & Mainly nurse & No \\
\hline 18 & {$[43,44]$} & $\begin{array}{l}\text { Psychiatric ward in a university hospital; } 10 \\
\text { nursing encounters }\end{array}$ & Patient initiatives during assessment and planning of care & $\begin{array}{l}\text { Videotaped nursing assessments and planning } \\
\text { sessions, supported with interviews with nurses }\end{array}$ & Qualitative content analysis & Both & No \\
\hline 19 & [45] & $\begin{array}{l}\text { Seven clinical areas within an NHS; } 85 \\
\text { nurse-patient interactions }\end{array}$ & $\begin{array}{l}\text { Communication styles, education skills and } \\
\text { pharmacological knowledge of nurses giving medical } \\
\text { education }\end{array}$ & $\begin{array}{l}\text { Audio recordings and observations of } \\
\text { nurse-patient interactions, supplemented with } \\
\text { post-interaction interviews }\end{array}$ & Qualitative content analysis & Both & Yes \\
\hline 20 & [46] & Two home care agencies; 6 nurses; 25 patients & $\begin{array}{l}\text { Relational and content aspects of compliance during } \\
\text { nursing home visits in the community }\end{array}$ & $\begin{array}{l}\text { Field notes during participant observation, } \\
\text { supported with interviews }\end{array}$ & $\begin{array}{l}\text { Content analysis, analysis } \\
\text { of relational dimension }\end{array}$ & Both & Yes \\
\hline 21 & [47] & Radiation therapy, 17 nurses; 5 patients & $\begin{array}{l}\text { Interaction and communication during the process of } \\
\text { internal radiation in isolation rooms }\end{array}$ & $\begin{array}{l}\text { Unmanned video recordings of real live } \\
\text { interaction in patient rooms }\end{array}$ & $\begin{array}{l}\text { Content analysis, time } \\
\text { analysis }\end{array}$ & Mainly nurse & Yes \\
\hline
\end{tabular}


Caris-Verhallen, W., Timmermans, L., Dulmen, S. van

Observation of nurse-patient interaction in oncology: review of assessment instruments.

Patient Education and Counseling: 54, 2004, p. 307-320

Table 3

Quantitative studies in nursing practice

\begin{tabular}{|c|c|c|c|c|c|c|c|}
\hline & Source & Setting and sample & Study focus & Data collection & Coding system & $\begin{array}{l}\text { Interaction } \\
\text { partners } \\
\text { considered }\end{array}$ & $\begin{array}{l}\text { Cues for instrument } \\
\text { development in } \\
\text { oncology }\end{array}$ \\
\hline 1 & [49] & $\begin{array}{l}\text { Workshops in cancer care; } 218 \\
\text { healthcare professionals }\end{array}$ & $\begin{array}{l}\text { The effects of a training programme in } \\
\text { terms of skills improvement }\end{array}$ & $\begin{array}{l}\text { Transcripts of audiotaped interviews with } \\
\text { simulated patients }\end{array}$ & $\begin{array}{l}\text { CRCIRM; molecular coding of individual utterances, } \\
\text { providing a rating of formm function. content and structure }\end{array}$ & Both & Yes \\
\hline 2 & [50] & $\begin{array}{l}\text { Residential workshop in cancer } \\
\text { care; } 5 \text { workshops, each with } 10-15 \\
\text { attendants }\end{array}$ & $\begin{array}{l}\text { The effects of a training programme in } \\
\text { terms of skills improvement }\end{array}$ & $\begin{array}{l}\text { Transcripts of audiotaped interviews with } \\
\text { simulated patients }\end{array}$ & $\begin{array}{l}\text { Adaptation of CRCIRM; molecular coding of unterances } \\
\text { providing a rating of form function, content, relevance, } \\
\text { psychological level, cue-related blocking behaviour, control }\end{array}$ & $\begin{array}{l}\text { Mainly healthcare } \\
\text { worker }\end{array}$ & Yes \\
\hline 3 & [52] & $\begin{array}{l}\text { Workshops in cancer care; } 25 \\
\text { healthcare professionals }\end{array}$ & $\begin{array}{l}\text { The effects of a training programme, } \\
\text { with standardized role-plays, and different } \\
\text { emotional scenarios }\end{array}$ & Transcriptions of tape-recorded interviews & $\begin{array}{l}\text { French translation of CRCIRM; molecular coding of } \\
\text { utterances providing a rating of form, function and structure }\end{array}$ & $\begin{array}{l}\text { Mainly healthcare } \\
\text { provider }\end{array}$ & Yes \\
\hline 4 & [33] & $\begin{array}{l}\text { Residential workshop in cancer care; } \\
16 \text { healthcare professionals }\end{array}$ & $\begin{array}{l}\text { The effects of a workshop in terms of } \\
\text { skills improvement }\end{array}$ & Audiotaped interviews & $\begin{array}{l}\text { Modified-scale CRCIRM; combining molar and molecular } \\
\text { coding on structure, skills, style and outcome of the interview }\end{array}$ & Mainly nurse & Yes \\
\hline 5 & [54] & Two hospices; 33 nurses & $\begin{array}{l}\text { The effects of training communication } \\
\text { skills in terms of clinical outcome, i.e. } \\
\text { eliciting patients' concerns }\end{array}$ & $\begin{array}{l}\text { Tape-recorded assessment interviews of } \\
\text { nurses with patients, supported with } \\
\text { patient interviews }\end{array}$ & $\begin{array}{l}\text { Using the concern checklist it was assessed: which concerns } \\
\text { patients disclosed and what concerns nurses listed }\end{array}$ & Both & Yes \\
\hline 6 & [56] & $\begin{array}{l}\text { Hospital palliative care, community } \\
\text { paplliative care; } 1 \text { clinical nurse } \\
\text { specialists; } 449 \text { patients }\end{array}$ & $\begin{array}{l}\text { The effect of clinical supervision on } \\
\text { transfer of communication skills after } \\
\text { training }\end{array}$ & $\begin{array}{l}\text { Direct coding of audiotaped nurse-patient } \\
\text { interactions }\end{array}$ & $\begin{array}{l}\text { Rated behaviours: interviewers' skills, patient disclosure, } \\
\text { interviewer's cue response }\end{array}$ & Both & Yes \\
\hline 7 & [58] & $\begin{array}{l}\text { Acute medical geriatric wards; } 24 \\
\text { patients }\end{array}$ & Activity level of elderly patients & $\begin{array}{l}0 \min \text { periods of non-participant direct } \\
\text { servations, using a microcomputer }\end{array}$ & $\begin{array}{l}\text { Molar coding of } 16 \text { behavioural categories, such as } \\
\text { interaction with others, posture. non-interactive behas }\end{array}$ & Patient & No \\
\hline 8 & [59] & $\begin{array}{l}\text { Two rehabilitation wards in a } \\
\text { geriatric hospital; } 32 \text { patients }\end{array}$ & $\begin{array}{l}\text { Styles of staff-patient interactions during } \\
\text { morning routines, and the effects on } \\
\text { elderly patients in rehabilitation care }\end{array}$ & $\begin{array}{l}\text { Non-participant structured observations } \\
\text { during morning care }\end{array}$ & $\begin{array}{l}\text { Godlove schedule; molar coding of styles of unrse-patient } \\
\text { interactions: physical activity, verbal guidance, etc. }\end{array}$ & Nurse & No \\
\hline 9 & [60] & $\begin{array}{l}\text { Two wards in a psycho-geriatric } \\
\text { clinic: } 22 \text { nurses: } 39 \text { patients }\end{array}$ & $\begin{array}{l}\text { The effects of an intervention on quality } \\
\text { of nurse-patient cooperation }\end{array}$ & $\begin{array}{l}\text { Non-participatory observation of moming } \\
\text { care. supplemented with field notes }\end{array}$ & Molar coding of 10 cooperation styles & Both & No \\
\hline 10 & [61] & $\begin{array}{l}\text { Two continuing care units; } 24 \text { staff; } \\
24 \text { patients }\end{array}$ & Interaction level of elderly patients & Time sampling-based field observation & $\begin{array}{l}\text { Molar coding of activity categories, such as informal } \\
\text { activity, asleep, organized activity }\end{array}$ & Mainly patient & No \\
\hline 11 & [62] & $\begin{array}{l}\text { Geriatric ward; small sample of } \\
\text { staff; representative sample of } \\
\text { patients; } 24 \text { taped } 2 \mathrm{~h} \text { periods }\end{array}$ & $\begin{array}{l}\text { Verbal strategies of qualified and } \\
\text { unqualified nursing personnel }\end{array}$ & $\begin{array}{l}\text { Tape-recorded interactions, using a } \\
\text { walkman tape recorder }\end{array}$ & $\begin{array}{l}\text { Molecular coding of } 15 \text { verbal communication categories: } \\
\text { explanation, offering choice, jokes and puns }\end{array}$ & Nurse & No \\
\hline 12 & [63] & $\begin{array}{l}\text { Two geriatric wards in a psychiatric } \\
\text { unit; } 27 \text { nurses; } 47 \text { patients }\end{array}$ & $\begin{array}{l}\text { Improving nurse-patient interaction by } \\
\text { establishing formal activity periods }\end{array}$ & $\begin{array}{l}\text { Non-participant observation using time } \\
\text { sampling }\end{array}$ & $\begin{array}{l}\text { Molecular coding of } 16 \text { behavioural categories, such as } \\
\text { informing, questions, general conversation }\end{array}$ & Nurse & No \\
\hline 13 & [64] & $\begin{array}{l}\text { Nine hospital elderly care wards; } 72 \\
\text { nurses }\end{array}$ & $\begin{array}{l}\text { The influence of ward organization on } \\
\text { nurse-patient interaction }\end{array}$ & $\begin{array}{l}\text { Non-participant observation using } \\
\text { computerized event recording }\end{array}$ & $\begin{array}{l}\text { Categories of verbal interactions: questions, commands, } \\
\text { explanations }\end{array}$ & Nurse & No \\
\hline 14 & [66] & $\begin{array}{l}\text { Home care; home for the elderly; } 47 \\
\text { nurses; } 241 \text { patients }\end{array}$ & $\begin{array}{l}\text { The effects of communication training } \\
\text { based on video interaction analysis }\end{array}$ & $\begin{array}{l}\text { Observation of real live videotaped } \\
\text { interaction }\end{array}$ & $\begin{array}{l}\text { explatarionis } \\
\text { RIAS adaptation for elderly nursing; molecular coding of } \\
\text { unterances; } 11 \text { verbal affective categories and } 13 \text { verbal } \\
\text { intstumental categories; } 5 \text { noviverbal categories; } 7 \text { global } \\
\text { affect ratings }\end{array}$ & Mainly nurse & Yes \\
\hline 15 & {$[67,68]$} & $\begin{array}{l}25 \text { family planning services; } 61 \\
\text { healthcare providers (most of the } \\
\text { nurses); } 178 \text { counseling sessions }\end{array}$ & $\begin{array}{l}\text { Patient's participation in family planning } \\
\text { consultations }\end{array}$ & Transcriptions of audiotaped consultations & $\begin{array}{l}\text { RIAS adaptation for family planning; molecular coding of } \\
\text { unterances, assessing interaction style, balance of talk, } \\
\text { clients' active communication, providers' promoting and } \\
\text { rewarding communication }\end{array}$ & Both & Yes \\
\hline 16 & {$[14,69]$} & $\begin{array}{l}\text { Oncology wards in three general } \\
\text { hospitals; } 50 \text { nurses; } 50 \text { simulated } \\
\text { patients; } 134 \text { real patients }\end{array}$ & $\begin{array}{l}\text { The effects of training communication } \\
\text { skills in terms of communication } \\
\text { competence and performance }\end{array}$ & $\begin{array}{l}\text { Videotaped nurse-simulated patient } \\
\text { interactions and videotaped real live } \\
\text { interactions }\end{array}$ & $\begin{array}{l}\text { RIAS adaptation for cancer nursing; unterance by utterance } \\
\text { coding of } 13 \text { verbal affective categories and } 18 \text { verbal } \\
\text { instrumental categories; } 5 \text { nonverbal categories }\end{array}$ & Mainly nurse & Yes \\
\hline 17 & [10] & $\begin{array}{l}\text { Six wards in two general hospitals; } \\
54 \text { nurses; } 162 \text { patients }\end{array}$ & $\begin{array}{l}\text { The extent to which nurses facilitate or } \\
\text { block patients in oncology nursing care }\end{array}$ & $\begin{array}{l}\text { Transcriptions of audiotaped nursing } \\
\text { histories }\end{array}$ & $\begin{array}{l}14 \text { facilitating behaviours, such as open questions, empathy; } \\
13 \text { blocking behaviours, such as inappropriate advice, } \\
\text { defending }\end{array}$ & Mainly nurse & Yes \\
\hline 18 & [70] & $\begin{array}{l}\text { Several areas of oncology nursing; } \\
110 \text { nurses; } 290 \text { nursing assessments }\end{array}$ & $\begin{array}{l}\text { The effect of a training course on nurses' } \\
\text { communication skills and confidence in } \\
\text { difficult situations }\end{array}$ & Audiotaped nursing assessments & $\begin{array}{l}\text { Molar coding of key areas in nursing assessment, such as } \\
\text { introduction; understanding of admission; awareness of } \\
\text { diagnosis; history present illhess }\end{array}$ & Nurse & Yes \\
\hline 19 & [71] & $\begin{array}{l}\text { Emergency and trauma center; } 40 \\
\text { nurse-patient interactions }\end{array}$ & $\begin{array}{l}\text { The amount of verbal and nonverbal } \\
\text { communication occurring between nurses } \\
\text { and trauma victims }\end{array}$ & $\begin{array}{l}\text { Direct observation of videotaped verbal } \\
\text { and nonverbal interaction }\end{array}$ & $\begin{array}{l}\text { With the Moore-Schwartz data collection tool, the amount } \\
\text { of verbal and nonverbal communication with patients and } \\
\text { family members is rated }\end{array}$ & Nurse & No \\
\hline 20 & [72] & $\begin{array}{l}\text { Adolescent unit for mentally ill } \\
\text { patients; } 15 \text { nurses; } 743 \text { interactions }\end{array}$ & $\begin{array}{l}\text { Nurses' interactions with mentally ill } \\
\text { young people }\end{array}$ & $\begin{array}{l}4 \mathrm{~h} \text { periods of participant observation by } \\
\text { a nurse researcher }\end{array}$ & $\begin{array}{l}\text { Using a coding grid the interaction was assessed on } \\
\text { location, initiation and nature }\end{array}$ & Mainly nurse & No \\
\hline 21 & [73] & Intensive therapy unit; 8 nurses & $\begin{array}{l}\text { The state of communication between } \\
\text { intubated patients and nurses }\end{array}$ & $\begin{array}{l}2 \mathrm{~h} \text { periods of non-participant observation; } \\
\text { observational data were supplemented } \\
\text { with structured interviews with nurses }\end{array}$ & $\begin{array}{l}\text { Ashworth's observation chart, coding the length of } \\
\text { interaction, initiator, nurses verbal content, touch, eye contact, } \\
\text { patients' verbal content, means of reply of the patient }\end{array}$ & Both & No \\
\hline 22 & {$[74]$} & Critical care unit; 30 nurses & $\begin{array}{l}\text { Effectiveness of communication between } \\
\text { nurses and ventilated patients }\end{array}$ & $\begin{array}{l}\text { Non-participant } 30 \text { min interval observation } \\
\text { supplemented with nurses' questionnaires }\end{array}$ & $\begin{array}{l}\text { Molar coding of actions and reactions of nurses, related to } \\
\text { the perceived level of consciousness of ventilated patients }\end{array}$ & Mainly nurse & No \\
\hline 23 & [75] & $\begin{array}{l}\text { Six workshops of adherence } \\
\text { promotion; } 60 \text { healthcare } \\
\text { professionals; } 120 \text { interactions }\end{array}$ & $\begin{array}{l}\text { The effect of a training programme on } \\
\text { adherence promotion skills }\end{array}$ & $\begin{array}{l}\text { Observation of videotaped interactions } \\
\text { between healthcare professionals and } \\
\text { standardized patients }\end{array}$ & $\begin{array}{l}\text { Coding system "adherence promotion counseling skills", } \\
\text { rating four skills categories: relation building, interviewing } \\
\text { skills; problem identification; behavioural interventions }\end{array}$ & $\begin{array}{l}\text { Mainly healthcare } \\
\text { provider }\end{array}$ & Yes \\
\hline
\end{tabular}


Caris-Verhallen, W., Timmermans, L., Dulmen, S. van

Observation of nurse-patient interaction in oncology: review of assessment instruments.

Patient Education and Counseling: 54, 2004, p. 307-320

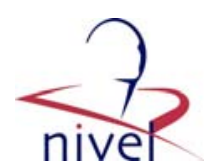

Table 4

Descriptive data for instruments using quantitative data and offering starting points for sequential analysis

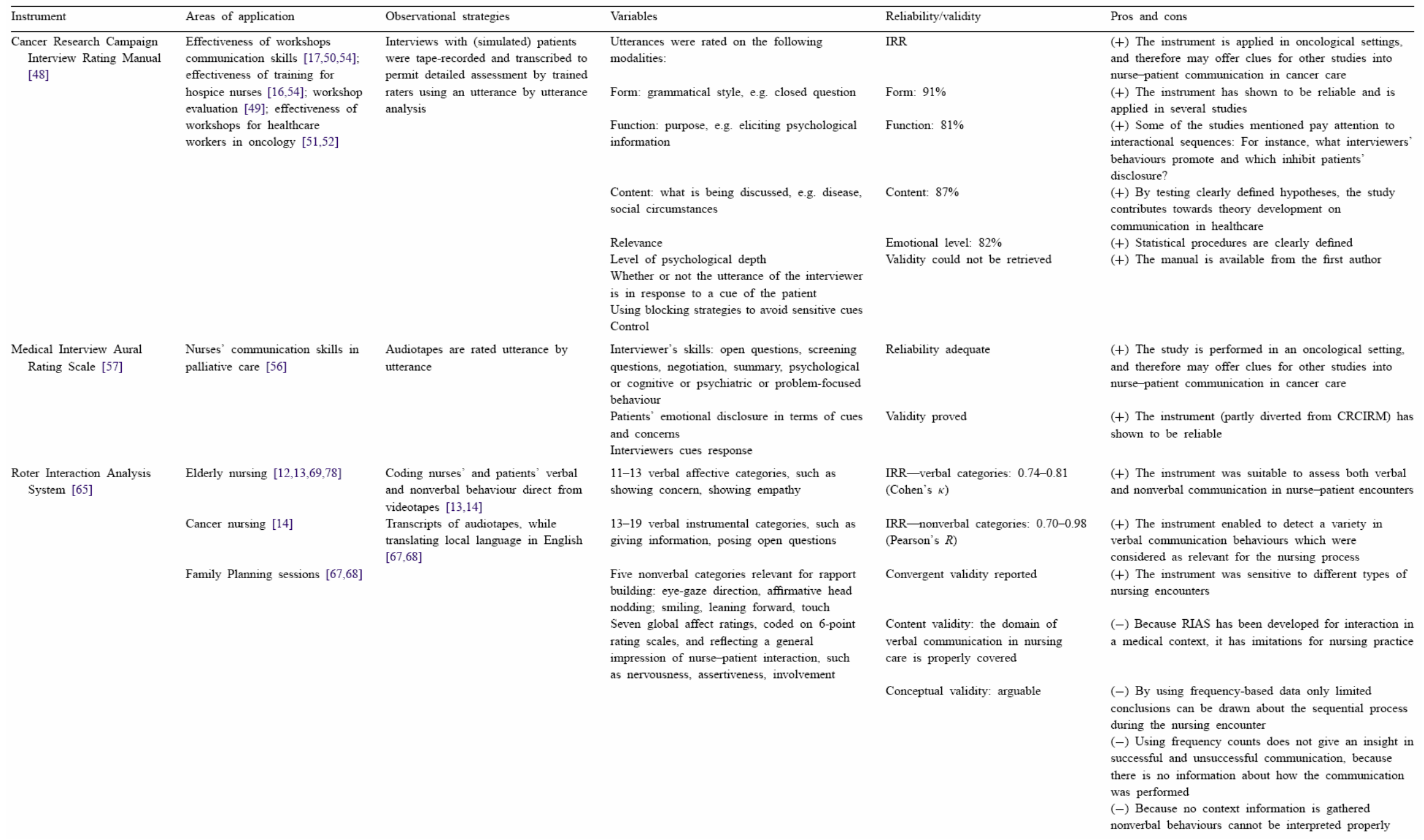




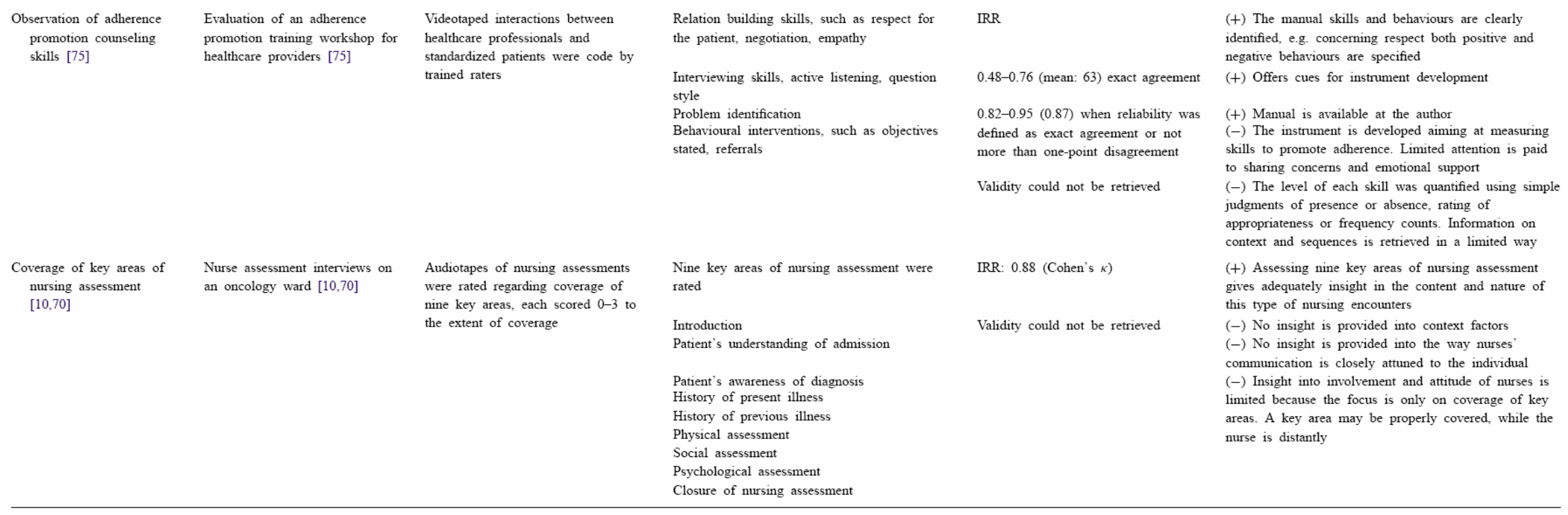

